Chirurgia (2019) 114: 650-658

No. 5, September - October

Copyright@ Celsius

http://dx.doi.org/10.21614/chirurgia.114.5.650

\title{
Can Morphological and Molecular Parameters of the Primary Breast Tumor Predict the Positivity of Nonsentinel Lymph Nodes After Positive Sentinel Lymph Node Biopsy?
}

\author{
Orsolya Hankó-Bauer', Cristian Podoleanu ${ }^{2}$, Rares Georgescu', Simona Stolnicu ${ }^{3}$ \\ 'Department of Surgery, University of Medicine, Pharmacy, Sciences and Technology of Targu Mures, Romania \\ 2Department of Internal Medicine, University of Medicine, Pharmacy, Sciences and Technology of Targu Mures, Romania \\ ${ }^{3}$ Department of Pathology, University of Medicine, Pharmacy, Sciences and Technology of Targu Mures, Romania
}

Corresponding author:

Assoc. Prof. Dr. Cristian Podoleanu, MD. PhD Department of Internal Medicine University of Medicine, Pharmacy, Sciences and Technology of Tirgu Mures, Romania Str. Gh. Marinescu nr. 1, 540099 Tirgu Mures E-mail: podoleanu@me.com

\section{Abbreviations:}

SLN - Sentinel Lymph Node: NSLN - Nonsentinel Lymph Nodes; NST - No Special Type): LNR - Lymph Node Rate.

\section{Rezumat}

Parametrii morfologici și moleculari ai tumorii mamare primare pot prezice statusul limfonodulilor axilari non-santinelă în cazul limfonodulilor santinelă pozitivi?

Introducere: biopsia limfonodulului santinelă (BLS) reprezintă metoda standard de evaluare a statusului axilar la pacientele cu carcinom mamar. $\mathrm{Cu}$ excepția cazurilor care îndeplinesc criteriile Z0011, evidarea axilară este necesara. Obiectivul studiului a fost de a evalua care dintre parametrii morfologici sau moleculari ai tumorii mamare primare pot prezice statusul limfonodulilor nonsantinelă cu scopul de a evita limfadenectomia axilară la pacientele cu limfonoduli santinelă pozitivi.

Material şi Metodă: a fost efectuat un studiu retrospectiv pe 170 paciente consecutiv diagnosticate cu carcinom mamar, la care a fost efectuată BLS pentru stadializare.

Rezultate: 42 (24\%) din cazuri au prezentat metastaze în limfonodulul santinelă, din care 11 cazuri au prezentat micrometastaze iar 6 cazuri au îndeplinit criteriile Z0011 (disecția axilară nu a fost necesară). Din cele 25 de paciente la care s-a efectuat disecție axilară doar 7 cazuri $(28 \%)$ au prezentat metastaze în limfonodulii non-santinelă. În cazuistica noastră doar diametrul tumorii primare $>20 \mathrm{~mm}$ poate prezice prezența metastazelor în ganglionul nonsantinelă ( $\mathrm{p}=0.058$; CI: 0,05787to 0,8224). Vârsta $(\mathrm{p}=0.280$; CI:0,7544 to 7,998), subtipul microscopic $(\mathrm{p}=0.231$; CI: 0.05374 to 9.271$)$, gradul microscopic $(p=0.929$; CI: 0.2351 to $3.515)$, profilul molecular al tumorii primare ( $\mathrm{p}=0.362$;CI: 0,2416 
to 4,663), numărul de limfonoduli santinelă cu metastaze ( $\mathrm{p}=0.378 ; \mathrm{CI}: 0,1083$ to 1,570 ), prezen-

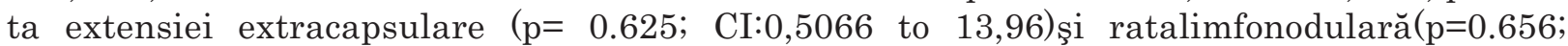
CI:0,5068 to 5,768$)$ nu pot prezice prezenta metastazelor în limfonodulii non-santinelă axilari. Concluzie: În cazurile în care pacienta nu îndeplineşte criteriile Z0011 si/sau aceste criterii nu sunt aplicate, disecția axilară este necesară.

Cuvinte cheie: carcinom mamar, metastaze, limfonodul santinelă

\section{Abstract}

Background: Sentinel lymph node (SLN) biopsy is the gold standard in the evaluation of the axillary status in patients with breast cancer. In cases meeting the Z0011 criteria, no further surgery is needed, while in the remaining cases axillary dissection is required. The aim of the study was to evaluate which morphological and molecular parameters of primary breast tumor or positive SLN can predict the positivity of nonsentinel lymph nodes (NSLN) in order to avoid unnecessary axillary lymphadenectomy.

Methods: We conducted a retrospective study on 170 consecutive invasive breast carcinomas, in which SLN biopsy was performed for staging.

Results: 42 (24\%) cases presented SLN metastases, of which 11 were micrometastases, 6 cases met the Z0011 criteria, requiring no subsequent surgery. 25 patients underwent subsequent ANLD, but only 7 cases $(28 \%)$ had positive NSLN. In this series, only the tumor diameter $>20 \mathrm{~mm}$ can predict positive nonsentinel lymph nodes $(p=0.058$; CI: 0.05787 to 0.8224$)$. Other parameters such as patient's age ( $p=0.280$; CI:0.7544 to 7.998), histological type ( $p=0.231$; CI: 0.05374 to 9.271), histological grade ( $\mathrm{p}=0.929$; CI: 0.2351 to 3.515 ), molecular profile of the tumor ( $\mathrm{p}=0.362$; CI: 0.2416 to 4.663), number of positive SLN ( $\mathrm{p}=0.378$; CI: 0.1083 to 1.570), presence of extracapsular extension ( $\mathrm{p}=0.625$; CI: 0.5066 to 13.96$)$ and lymph node ratio ( $\mathrm{p}=0.656$; CI: 0.5068 to 5.768$)$ cannot predict the presence of metastasis in the NSLN.

Conclusion: In cases in which the patient does not meet the Z0011 criteria and/or these criteria are not used, axillary lymph node dissection is the surgical treatment of choice.

Key words: breast cancer, metastasis, sentinel lymph node

\section{Introduction}

Metastasis in axillary lymph nodes is considered the most important prognostic factor in breast cancer. It determines, on the one hand, surgical and oncological therapeutic management and, on the other hand, it plays an important role in the survival of the patient $(1,2)$. As such, the correct assessment of axillar status is mandatory (3).

Prior to the year 2011 the gold standard management of the axilla consisted of clinical evaluation and preoperative imaging of the axilla to detect the presence of metastases into the lymph nodes. The lymph nodes considered suspicious on ultrasound were subjected to biopsy, and, if malignancy was confirmed, a radical surgical treatment of axillary lymph node surgery was performed, in which all homolateral axillary lymph nodes (station 1 and 2) were removed in block, a procedure associated with increased morbidity (4).

If no suspicious lymph nodes are found on ultrasound or palpation, biopsy of the sentinel lymph node (SLN) is performed, a gold standard intervention for the evaluation of the axilla. In cases in which the SLN is negative (no metastasis), no further surgery is needed (5). 
Prior to the year 2011, dissection of the positive SLN was considered necessary. However, in 2011, the ASCGO Z011 trial set the criteria by which the patient with an early-stage breast carcinoma (T1,2) and 1-2 positive SLNs does not have to undergo dissection of the axillary lymph node if breast preservation surgery is opted for, followed by breast and axillary radiotherapy. The recurrence rate in patients who avoided axillary dissection in this study was only $0.9 \%$, distant events to a very little extent, and survival identical to those in whom the axilla was dissected (3).

Thus, by identifying these criteria, a considerable number of patients may avoid practically unnecessary surgery associated with significant morbidity.

The ASCGO Z011 trial as well as the subsequent AMAROS trial (2014) (patients with limited sentinel node metastases can be treated with axillary radiotherapy and could be spared an axillary lymph node dissection without compromising locoregional control or survival outcome) changed the way of approaching the axilla in patients with earlystage breast carcinoma and the results were accepted and included in the American NCCN guide $(6,7)$, although not all the medical and scientific community accepts this approach to the axilla (several centers in the US and fewer ones in Europe) (8). Furthermore, by avoiding the dissection of the other nonsentinel lymph nodes (NSLN) one may contribute to a lack of information regarding the number and status of the axilla and the stage of the tumor, which leads to the alteration in the local and systemic management in some cases, not necessarily in favor of the patient.

On the other hand, even when applying the Z0011 criteria, it was found that most of the patients who do not meet the Z0011 criteria and in whom the axillary lymph nodes are dissected do not show metastases (personal unpublished data) and in such cases the dissection could be avoided if a number of morphological and/ or molecular parameters were identified to predict the status of these lymph nodes.
The purpose of our study was to evaluate the morphological and molecular parameters of the primary tumor and the positive SLN associated with positive NSLNs in order to predict the status of the NSLNs without their surgical removal and morphological evaluation so as to reduce the number of unnecessary axillary lymph node dissections in patients who do not meet the Z0011 criteria or those in whom the Z0011 criteria are not accepted and applied by the multidisciplinary team.

\section{Material and Method}

\section{Patient selection}

We performed a retrospective study of 170 consecutive patients with invasive breast cancer diagnosed following tru-cut biopsy who underwent SLN biopsy between 2012-2016 associated with mastectomy or breast conservative surgery, patients with negative axilla on clinical and ultrasound examination.

\section{Exclusion criteria}

We excluded patients whose axillary lymph nodes were suspicious of malignancy. Patients who received neoadjuvant chemotherapy were also excluded.

\section{The Sentinel Node Biopsy Method}

On the day of the surgery, in the nuclear medicine department, the patients received periareolar and/ or peritumoral TC99 injection, followed by lymphoscintigraphy to visualize the radioactive nodes in the axilla. Intraoperatively, the radioactive nodes were detected by gamma-ray probe (Neoprobe 2000). The target count 10-second cumulative radioactivity of the node was measured both in vivo and ex vivo. Resting axial radioactivity (residual activity) was checked after removal of the sentinel lymph node/ nodes. In each case in which the residual activity did not exceed 10\% of the aggregate activity of the last excised SLN, we considered that there were no other sentinel nodes and surgery was finished. 


\section{Axillary lymph node dissection}

Patients who had a positive SLN and did not meet the Z0011 criteria were subjected to axillary lymph node dissection. In a second surgical procedure, all the lymph nodes from the upper axilla to the axillary vein, laterally up to the large dorsal and medially to the edge of the pectoral muscle were removed, preserving important vascular and nervous elements (thoraco-dorsal group, subscapular, long thoracic nerve, and intercostobrachial nerve).

\section{Morphological Examination}

The macroscopic and microscopic examination of dissected sentinel lymph nodes was performed by a single pathologist with extensive experience in breast pathology (SS). Microscopic appearance and evaluation of metastasis in SLN as well as the size of metastasis and extracapsular extension were assessed according to pTNM (9). The microscopic classification of the primary breast tumor was performed according to the 2012 WHO classification (10) and microscopic grading according to the modified Elston-Ellis method (11). The molecular profile was established according to molecular classification (12) by analyzing the surrogate immunohistochemical markers (ER, PR, ki67, HER2), performed in each case diagnosed with infiltrative breast carcinoma and included in the study. The lymph node rate (LNR) was calculated as the rate between the number of positive lymph nodes and the number of excised lymph nodes.

\section{Statistical Analysis}

Statistical analysis of data was performed using GraphPad Prism6 for Windows. Descriptive statistics were used for continuous variables. Comparison of tumor and axillary lymph node characteristics was performed using the Chi square and Fisher tests, RR. All tests were 2 -tailed and $p<0.05$ was considered statistically significant. We also considered statistically significant the $95 \%$ confidence interval excluding the value of 1 .

The Ethical Committee of the University of Medicine and Pharmacy of Tîrgu Mureş approved this study.

\section{Results}

One hundred-seventy consecutive patients received SLN biopsy, mean age 56.17 years (minimum 27 years, maximum 80 years). Of these, 42 cases $(24 \%)$ had metastases in the SLN, 11 micrometastases and 31 macrometastases.

Of the 31 cases with macrometastases in the SLN, 6 met the Z0011 criteria (patients underwent breast preservation surgery, did not benefit from neoadjuvant chemotherapy, and had no more than 2 positive sentinel lymph nodes), and the rest of 25 cases were subjected to axillary lymph node dissection.

Of the 25 cases that were subjected to axillary lymph node dissection, only 7 cases (28\%) had metastatic lymph nodes in the remaining of the axilla, and in 18 cases $(72 \%)$ the histopathological examination did not reveal metastatic lymph nodes in the rest of the axilla.

Patients who only had micrometastases in the sentinel lymph node were subjected to periodic imaging follow-up.

Patients were divided into two groups according to age: under 40 and over 40 years of age. Statistical analysis did not show a significant difference in age correlated with the occurrence of metastasis in the NSLN $(p=0.280 ; R R=4$, CI: 0.7544 to 7.998$)$.

The mean diameter of primary tumors associated with axillary dissection was 20.32 $\mathrm{mm}$ (minimum $10 \mathrm{~mm}$, maximum $35 \mathrm{~mm}$ ). The statistical analysis shows a significant association between the primary tumor diameter and the presence of metastases in NSLN ( $p=0.0580 ; R R=0.225$, CI: 0.05787 to $0.8224)$.

Regarding the histological type of the 25 cases of primary tumors that were subjected to axillary lymph node dissection, 22 cases were NST (no special type) and 3 cases had other 
types of tumors (invasive lobular carcinoma, apocrine and mucinous). Of these, 6 cases of NST tumors and one other tumor case (lobular) had metastases in the axillary lymph nodes on axillary lymph node dissection. The statistical analysis does not show a statistically significant difference between the different histological types of tumors and the positivity of the NSLN $(\mathrm{p}=0.231 ; \mathrm{RR}=0.782$, CI: 0.05374 to 9.271 ).

Of the 25 cases subjected to axillary lymph node dissection, we encountered 11 cases of histological grade 1, 10 of grade 2, and 4 of grade 3 malignancy. We did not find a statistically significant difference between the grade of primary tumor malignancy and axillary metastases in NSLN $(p=0.929 ; \mathrm{RR}=0.909$, CI: 0.2351 to 3.515 ).

Regarding the molecular profile of the primary tumor, of the 25 cases that were subjected to axillary lymph node dissection, 10 cases (40\%) had Luminal A profile, 2 cases (8\%) Luminal B, and 13 cases (52\%) proliferative Luminal B. We found no statistically significant difference between the molecular profile of the primary tumor and the presence of metastases in NSLN $(p=0.365 ; \mathrm{RR}=0.8$, CI: 0.2416 to 4.663 ).

The mean number of excised sentinel nodes was 2.56 (minimum 1, maximum 6), and the mean number of sentinel lymph nodes with macrometastases was $1.48(\min 1, \max 4)$. We did not find any statistically significant difference between the number of positive SLNs and positive NSLNs $(\mathrm{p}=0.378 ; \mathrm{RR}=$ 0.433 , CI: 0.1083 to 1.570 )

Extracapsular extension (ECE) was identified in 7 cases of positive SLN, of which 6 had metastases in NSLNs. Although it is a remarkable percentage, it is not statistically significant $(p=0.625 ; R R=2.333, C I: 0.5066$ to 13.96). The lymph node rate (LNR) was calculated as the rate between the number of positive lymph nodes and the number of excised lymph nodes. The mean lymphonodular rate was 0.65 . We did not find a statistically significant difference between LNR and the positivity of NSLNs $(p=0.656$; $\mathrm{RR}=1.697$, CI: 0.5068 to 5.768) (Table 1).

\section{Discussion}

The presence of residual axillary disease following positive SLN biopsy is a muchdebated topic in the literature. For this purpose, prior to the Z0011 trial, various nomograms were developed by major oncology research centers that allow, based on the analysis of some parameters, the inclusion of breast cancer patients in different risk groups to develop residual axillary disease, thus to allow the avoidance of axillary lymphadenectomy in some selected patients $(12,13,14)$.

By studying the 170 consecutive cases of this series, after applying the Z0011 criteria, 25 cases were subject to axillary lymph node dissection, of which only 7 had residual disease in the axilla. Thus, we can state that 18 patients (72\%) underwent a practically unnecessary axillary surgery. This fact led us to carry out a study to identify the morphological and molecular parameters of the primary tumor and of the positive SLN associated with the positivity of the NSLNs to minimize the number of axillary lymph node dissection in patients who do not meet the Z0011 criteria.

In the literature, prediction factors for the positivity of the NSLNs are controversial.

A study published in 2005 by Barranger et al. included 337 patients who received SLN biopsy for breast cancer, of which 71 had axillary lymphadenectomy. This study concludes that the histological type of the primary tumor, tumor diameter, the number of positive SLNs and lymphonodular rate (sentinel lymph node) are significantly associated with the positivity of the NSLN in axillary dissection (15).

A meta-analysis published in 2011 by van at Parra et al. comprising 56 studies proves that the following individual characteristics are most likely associated with the positivity of the NSLN $(\mathrm{OR}>2)$ : lymphovascular invasion in the primary tumor, more than one positive SLN, macrometastases in the SLN, </= 1 negative SLN, presence of extracapsular extension, LNR> 0.5 (16).

Another study published in 2012 by Boler et al. argues that the presence of micrometastases 
Table 1. Associationbetween the morphological and molecular parameters of the primary tumor and the positivity of the nonsentinel lymph nodes. (Lum A-Luminal A; Lum B-Her2 pos-Luminal B Her2 positive, Lum B -Her 2 neg-Luminal B Her 2 negative, TN- triple negative, Her 2 Her overexpression, SLN-sentinel lymph node, ECE - extracapsular extension, LNR-lymph node ratio, RR-relative risk, Cl-confidence interval, OR-Odds Ratio)

\begin{tabular}{|c|c|c|c|c|c|}
\hline Variables & NSLN + & NSLN - & $p$ & RR & $\mathrm{Cl}$ \\
\hline $\begin{aligned} \text { Age } & <40 \\
& >40\end{aligned}$ & $\begin{array}{l}1 \\
6\end{array}$ & $\begin{array}{c}0 \\
18\end{array}$ & 0.280 & 4 & 0.7544 to 7.998 \\
\hline $\begin{array}{l}\text { Tumor diameter } \\
\quad<20 \\
>20\end{array}$ & $\begin{array}{l}2 \\
5\end{array}$ & $\begin{array}{c}14 \\
4\end{array}$ & 0.058 & 0.225 & 0.05787 to 0.8224 \\
\hline $\begin{array}{l}\text { Tumor histological type } \\
\text { NST } \\
\text { Other }\end{array}$ & $\begin{array}{l}6 \\
1\end{array}$ & $\begin{array}{c}16 \\
2\end{array}$ & 0.231 & 0.7826 & 0.05374 to 9.271 \\
\hline $\begin{array}{l}\text { Tumor histological grad } \\
\qquad \begin{array}{c}1 \\
2 \\
3\end{array}\end{array}$ & $\begin{array}{l}3 \\
3 \\
1\end{array}$ & $\begin{array}{l}8 \\
7 \\
3\end{array}$ & $\begin{array}{l}\text { referent } \\
1 \\
0.929\end{array}$ & $\begin{array}{c}0.9091 \\
1.091\end{array}$ & $\begin{array}{l}0.2351 \text { to } 3.515 \\
0.1547 \text { to } 7.691\end{array}$ \\
\hline $\begin{array}{l}\text { Tumor molecular profile } \\
\text { Lum A } \\
\text { Lum B-Her2 pos } \\
\text { Lum B-Her2 neg }\end{array}$ & $\begin{array}{l}4 \\
1 \\
2\end{array}$ & $\begin{array}{c}6 \\
1 \\
11\end{array}$ & referent & $\begin{array}{l}0.8 \\
2.6\end{array}$ & $\begin{array}{l}0.2416 \text { to } 4.663 \\
0.6712 \text { to } 10.64\end{array}$ \\
\hline $\begin{array}{c}\text { Number of }+ \text { SLN } \\
1 \\
>1\end{array}$ & $\begin{array}{l}2 \\
5\end{array}$ & $\begin{array}{c}10 \\
8\end{array}$ & 0.378 & 0.433 & 0.1083 to 1.570 \\
\hline $\begin{array}{c}\text { ECE yes } \\
\text { no }\end{array}$ & $\begin{array}{l}6 \\
1\end{array}$ & $\begin{array}{c}12 \\
6\end{array}$ & 0.625 & 2.333 & 0.5066 to 13.96 \\
\hline $\begin{array}{r}\mathrm{LNR}<0.5 \\
>0.5\end{array}$ & $\begin{array}{l}4 \\
3\end{array}$ & $\begin{array}{c}7 \\
11\end{array}$ & 0.656 & 1.697 & 0.5068 to 5.768 \\
\hline Variables & $\mathrm{NSLN}+$ & NSLN - & $p$ & $\mathrm{RR}$ & $\mathrm{Cl}$ \\
\hline $\begin{aligned} \text { Age } & <40 \\
& >40\end{aligned}$ & $\begin{array}{l}1 \\
6\end{array}$ & $\begin{array}{c}0 \\
18\end{array}$ & 0.280 & 4 & 0.7544 to 7.998 \\
\hline $\begin{array}{l}\text { Tumor diameter } \\
\quad<20 \\
>20\end{array}$ & $\begin{array}{l}2 \\
5\end{array}$ & $\begin{array}{c}14 \\
4\end{array}$ & 0.058 & 0.225 & 0.05787 to 0.8224 \\
\hline $\begin{array}{l}\text { Tumor histological type } \\
\text { NST } \\
\text { Other }\end{array}$ & $\begin{array}{l}6 \\
1\end{array}$ & $\begin{array}{c}16 \\
2\end{array}$ & 0.231 & 0.7826 & 0.05374 to 9.271 \\
\hline $\begin{array}{l}\text { Tumor histological grad } \\
1 \\
2 \\
3\end{array}$ & $\begin{array}{l}3 \\
3 \\
1\end{array}$ & $\begin{array}{l}8 \\
7 \\
3\end{array}$ & $\begin{array}{c}\text { referent } \\
1 \\
0.929\end{array}$ & $\begin{array}{c}0.9091 \\
1.091\end{array}$ & $\begin{array}{l}0.2351 \text { to } 3.515 \\
0.1547 \text { to } 7.691\end{array}$ \\
\hline $\begin{array}{l}\text { Tumor molecular profile } \\
\text { Lum A } \\
\text { Lum B-Her2 pos } \\
\text { Lum B-Her2 neg }\end{array}$ & $\begin{array}{l}4 \\
1 \\
2\end{array}$ & $\begin{array}{c}6 \\
1 \\
11\end{array}$ & referent & $\begin{array}{l}0.8 \\
2.6\end{array}$ & $\begin{array}{l}0.2416 \text { to } 4.663 \\
0.6712 \text { to } 10.64\end{array}$ \\
\hline $\begin{array}{c}\text { Number of }+ \text { SLN } \\
1 \\
>1\end{array}$ & $\begin{array}{l}2 \\
5\end{array}$ & $\begin{array}{c}10 \\
8\end{array}$ & 0.378 & 0.433 & 0.1083 to 1.570 \\
\hline $\begin{array}{c}\text { ECE yes } \\
\text { no }\end{array}$ & $\begin{array}{l}6 \\
1\end{array}$ & $\begin{array}{c}12 \\
6\end{array}$ & 0.625 & 2.333 & 0.5066 to 13.96 \\
\hline $\begin{aligned} \operatorname{LNR} & <0.5 \\
& >0.5\end{aligned}$ & $\begin{array}{l}4 \\
3\end{array}$ & $\begin{array}{c}7 \\
11\end{array}$ & 0.656 & 1.697 & 0.5068 to 5.768 \\
\hline
\end{tabular}

or extracapsular extension in the is a prediction vascular invasion, and tumor size over $2 \mathrm{~cm}$ factor for not having metastases in NSLNs, predispose to the presence of metastases in whereas histological type of tumor, lympho- NSLNs (17). 
In 2012, Mittendorf et al. published a study evaluating the prognostic factors for the positivity of the NSLN, a study which included 509 patients with positive SLN biopsy. Research results show that the number of SLN, the number of metastatic SLN, extracapsular extension, primary tumor diameter, and histological type of the primary tumor are factors associated with the positivity of the NSLNs (18).

The study published in 2013 by Yao-Lung Kuo, which validates the Memorial Sloan Kettering Cancer Center (MSKCC) nomogram (324 cases of positive SLN subjected to axillary dissection) claims that the tumor type, primary tumor diameter, microscopic grade, the number of positive SLN and that of negative ones are significantly associated with the positivity of the NSLN in axillary dissection and recommends the use of the nomogram to determine the risk of residual axillary disease after the biopsy of the positive SLN (19).

A study of 104 cases of SLN biopsy, of which $48 \%$ had metastases in NSLNs, concluded that the primary tumor diameter and the rate of positive lymph nodes were prognostic factors for the positivity of the NSLNs. At the same time, positive NSLNs are associated with HER2 + and HER2 overexpression luminal molecular profile of the primary tumor (20).

The results of the study published in 2015 by Chie Toshikawa et al. show that the diameter of the primary tumor is significantly associated with the positivity of the NSLN. The positivity of the SLN in this study was $15 \%(21)$.

In 2015, Naveen Padmanabhan et al. published an article in which the authors validate the MSKCC nomogram looking for prognostic factors for the positivity of the NSLN in the Indian population. The conclusion of the research is that the extracapsular extension and the number of positive SLNs are associated with positive NSLNs (22).

A study published in 2016 develops a prediction score for NSLNs positivity including 513 patients from 10 hospitals in the Netherlands. The study concludes that the strongest prediction factor for NSLN positivity is the size of the metastasis in the SLN (23).

Recently a study published study states that the extracapsular nodal extension in the sentinel lymph node is an important predictor for nonsentinel lymph node involvement. (24).

In our study, the factors most likely to be associated with the positivity of the NSLN after the biopsy of the positive SLN were the following: diameter $>20 \mathrm{~mm}$ of the primary tumor, the number of positive SLNs, extracapsular extension in the SLN, and lymphonodular rate. These parameters are similar to those studied in the literature before and after applying the Z0011 criteria (Table 2). Apart

Table 2. Similar studies in the literature highlighting prediction factors for the positivity of nonsentinel lymph nodes (SLNB-Sentinel lymph node biopsy, SLN-Sentinel lymph node, ALND-axillary lymph node dissection, LNR-lymph hode ratio, ECE extracapsular extension, LVI-lymphovascular invasion)

\begin{tabular}{|c|c|c|}
\hline Study & Number of cases & Predicting factors \\
\hline \multicolumn{3}{|c|}{ Studies published before the Z0011 trial } \\
\hline Barranger $\mathrm{E}$ [15] & 337 SLNB/71 ALND & Tumor histological type, tumor diameter, number of + SLN, LNR \\
\hline Van la Parra RF [16] & 56 studies & ECE, $>1+$ SLN, LNR $>0.5$ \\
\hline \multicolumn{3}{|c|}{ Studies published after the Z0011 trial } \\
\hline Boler DE [17] & 332 SLNB/116 ALND & Tumor histological type, presence of LVI, tumor diameter \\
\hline Mittendorf EA [18] & 509 ALND after SLNB & $\begin{array}{l}\text { Number of excised SLN, Number of +SLN, ECE, tumor histological } \\
\text { type and tumor diameter }\end{array}$ \\
\hline Kuo YL [19] & 324 ALND after SLNB & Tumor histological type, tumor diameter, number of +SLN \\
\hline Gólben K [20] & 104 SLNB/50 ALND & Tumor diameter, LNR, Tumor molecular profile \\
\hline Toshikawa C [21] & 358 SLNB/ 54 ALND & Tumor diameter \\
\hline Padmanabhan N [22] & 334 SLNB/ 64 ALND & ECE, number of + SLN \\
\hline Van den Hoven I [23] & 513 & Diameter of the sentinel SLN metastasis \\
\hline Schwentner L [24] & 324 & ECE \\
\hline
\end{tabular}


from the primary tumor diameter, all the other parameters refer to the status of the dissected SLN rather than to the morphological and molecular parameters of the primary tumor.

\section{Conclusion}

In our series of cases, none of the studied parameters of primary tumor (except primary tumor size) and SLN cannot predict the presence of metastasis in the NSLN. One of major possible reason is the limited number of patients included in the study (with HER2 positive as well as triple negative cases not being the subject of the present study). Future studies involving larger number of cases are needed. In cases in which the patient does not meet the Z0011 criteria or these criteria are not applied, the axillary lymph node dissection will remain the surgical treatment of choice, while the application of a nomogram is impractical in reducing the number of unnecessary axillary dissections.

\section{Acknowledgement}

We thank to Adrian Naznean from to Foreign Language Department, University of Medicine and Pharmacy of Tirgu Mures for carefully translating and editing the manuscript.

\section{Authors' Contributions}

SS designed the manuscript, OB wrote the manuscript, RG included and surgically treat the patiets, CP collected the data and did the statistical analysis.

\section{Disclosure}

The authors have no conflict of interest.

Sources of support: none.

\section{References}

1. Vinh-Hung V, Nguyen NP, Cserni G, Truong P, Woodward W, Verkooijen HM et al. Prognostic value of nodal ratios in node- positive breast cancer: a compiled update. Future Oncol. 2009; 5(10):1585-603.

2. Martin FT, O'Fearraigh C, Hanley C, Curran C, Sweeney KJ, Kerin MJ. The prognostic significance of nodal ratio on breast cancer recurrence and its potential for incorporation in a new prognostic index. Breast J. 2013;19(4):388-93.

3. Giuliano AE, Ballman K, McCall L, Beitsch P, Whitworth PW, Blumencranz $\mathrm{P}$, et al. Locoregional Recurrence After Sentinel Lymph Node Dissection With or Without Axillary Dissection in Patients With Sentinel Lymph Node Metastases: Long-term Follow-up From the American College of Surgeons Oncology Group (Alliance) ACOSOG Z0011 Randomized Trial, Ann Surg. 2016; 264(3):413-20.

4. Veronesi U, Paganelli G, Viale G, Luini A, Zurrida S, Galimberti V, et al. Sentinel-lymph-nodebiopsy as a stagingprocedure in breast cancer: update of a randomisedcontrolledstudy. The Lancet Oncology. 2006;7(12):983-90.

5. Lyman GH, Somerfield MR, Giuliano AE. Sentinel Lymph Node Biopsy for Patients With Early-Stage Breast Cancer: American Society of Clinical Oncology Clinical Practice Guideline Update, J Oncol Pract. 2017;13(3):196-198.

6. Gradishar WJ, Anderson BO, Balassanian R, Blair SL, Burstein HJ, Cyr A et al. NCCN Guidelines ${ }^{\circledR}$ Insights Breast Cancer, Version 1.2017 Featured Updates to the NCCN Guidelines, J Natl Compr Canc Netw. 2017;15(4):433-451.

7. Donker M, van Tienhoven G, Straver ME, Meijnen P, van de Velde CJH, Mansel RE, et al.Radiotherapy of surgery of the axilla after a positive sentinel node in breast cancer (EORTC 10981-22023 AMAROS: a randomized, multicenter, open-label, phase 3 noninferiority trial. Lancet Oncol. 2014;15(2):1303-1310.

8. Güth U, Myrick ME, Viehl CT, Schmid SM, Obermann EC, Weber WP. The post ACOSOG Z0011 era: Does our new understanding of breast cancer really change clinical practice? European Journal of Surgical Oncology (EJSO). 2012;38(8):645-50.

9. Giuliano AE, Connolly JL, Edge SB, Mittendorf EA, Rugo HS, Solin LJ, et al. Breast Cancer-Major changes in the American Joint Committee on Cancer eighth edition cancer staging manual. CA Cancer J Clin. 2017;67(4):290-303.

10. Lakhani S, Ellis IO, Schnitt SJ. World Health Organization classification of tumors of the breast. Lyon: IARC Press; 2012. p. 13-77.

11. Ellis I0, Elston CW. Histologic grade. In: O'Malley FP, Pinder SE, editors. Breast pathology. Philadelphia, PA: Elsevier; 2006. p. 225-33.

12. Goldhirsch A1, Wood WC, Coates AS, Gelber RD, Thürlimann B, Senn HJ et al. Strategies for subtypes--dealing with the diversity of breast cancer: highlights of the St. Gallen International Expert Consensus on the Primary Therapy of Early Breast Cancer 2011; Ann Oncol. 2011;22(8):1736-47.

13. Van Zee KJ, Manasseh DM, Bevilacqua JL, Boolbol SK, Fey JV, Tan LK, et al. A nomogram for predicting the likelihood of additional nodal metastases in breast cancer patients with a positive sentinel node biopsy, Ann Surg Oncol. 2003;10(10):1140-51.

14. Kohrt HE, Olshen RA, Bermas HR, Goodson WH, Wood DJ, Henry $S$, et al. Bay Area SLN Study., New models and online calculator for predicting non-sentinel lymph node status in sentinel lymph node positive breast cancer patients., BMC Cancer. 2008;8:66.

15. Barranger E, Coutant C, Flahault A, Delpech Y, Darai E, Uzan S. An axilla scoring system to predict non-sentinel lymph node status in breast cancer patients with sentinel lymph node involvement., Breast Cancer Res Treat. 2005;91(2):113-9.

16. van la Parra RF, Peer PG, Ernst MF, Bosscha K. Meta-analysis of predictive factors for non-sentinel lymph node metastases in breast cancer patients with a positive SLN. Eur J Surg Oncol. 2011; 37(4):290-9. 
17. Boler DE, Uras C, Ince U, Cabioglu N. Factors predicting the nonsentinel lymph node involvement in breast cancer patients with sentinel lymph node metastases, Breast. 2012;21(4):518-23.

18. MittendorfEA, Hunt KK, Boughey JC, Bassett R, Degnim AC, Harrell $R$, et al. Incorporation of sentinel lymph node metastasis size into a nomogram predicting nonsentinel lymph node involvement in breast cancer patients with a positive sentinel lymph node. Ann Surg. 2012;255(1):109-15.

19. Kuo YL, Chen WC, Yao WJ, Cheng L, Hsu HP, Lai HW, et al. Validation of Memorial Sloan-Kettering Cancer Center nomogram for prediction of non-sentinel lymph node metastasis in sentinel lymph node positive breast cancer patients an international comparison., Int J Surg. 2013;11(7):538-43.

20. Gülben K, Berberoğlu U, Aydoğan 0, Kınaş V. Subtype is a predictive factor of nonsentinel lymph node involvement in sentinel node-positive breast cancer patients., J Breast Cancer. 2014; 17(4):370-5.

21. Toshikawa C, Koyama Y, Nagahashi M, Tatsuda K, Moro K, Tsuchida J, et al. Predictive Factors for Non-Sentinel Lymph Node
Metastasis in the Case of Positive Sentinel Lymph Node Metastasis in Two or Fewer Nodes in Breast Cancer, J Clin Med Res. 2015; 7(8):620-6.

22. Padmanabhan N, Ayub MF, Hussain K, Kurien A, Radhakrishna S. Factors Influencing Non-sentinel Node Involvement in Sentinel Node Positive Patients and Validation of MSKCC Nomogram in Indian Breast Cancer Population., Indian J Surg Oncol. 2015; 6(4):337-45.

23. van den Hoven I, van Klaveren $D$, Voogd AC, Vergouwe $Y$, Tjan-Heijnen V, Roumen RM. A Dutch Prediction Tool to Assess the Risk of Additional Axillary Non-Sentinel Lymph Node Involvement in Sentinel Node-Positive Breast Cancer Patients, Clin Breast Cancer. 2016;16(2):123-30.

24. Schwentner L, Dayan D, Wöckel A, Janni W, Kreienberg R, Blettner $M$ et al. Is extracapsular nodal extension in sentinel nodes a predictor for nonsentinel metastasis and is there an impact on survival parameters?-A retrospective single center cohort study with 324 patients. Breast J. 2018;24(4):480-486. 